\title{
E-Voting Optimization For Head Of Community Unit (RW) Election with WAPT Testing
}

\author{
Samudi \\ STMIK Nusa Mandiri \\ Jakarta Selatan \\ Samudi.net@gmail.com
}

\author{
Herlambang Brawijaya \\ STMIK Nusa Mandiri \\ Jakarta Selatan \\ Herlambang.braw@gmail.com
}

\author{
Universitas Bina Sarana Informatika \\ Jakarta Barat. \\ slamet.smd@bsi.ac.id
}

\begin{abstract}
Conventional voting has several weaknesses, including difficulties in determining the validity of ballots, the slow ballot counting process, inaccurate ballot calculations, no copy of ballots if there is damage to the ballots, the difficulty of recalculation in the event of distrust results ballot calculations, prone to leakage of ballots, and the amount of the budget spent. From the problem above, the author proposes to design and build a system to implement elections using information technology called Electronic Voting. The method in this study uses the waterfall method which consists of the stages of communication needs, planning, modeling, construction, and distribution or implementation. The aim is to reduce the weaknesses that have occurred so far, reduce the paper during the election, and it is expected that the public interest in participating to vote will be greater and the selection process can run quickly and accurately. To produce quality E-Voting, WAPT testing is conducted (Web Application Load Stress and Performance Testing)
\end{abstract}

Keywords - Conventional Election, Waterfall, E-Voting

\section{INTRODUCTION}

Indonesia is one of the countries that adhere to a democratic system, one of which is that all citizens have equal rights to make decisions in every election. Such as the election of the head of state, governor, until the lowest level election, namely the election of the chairman of the community.

Based on governor's regulation no. 1 of 2016 (Pergub, 2016) Citizen Associations, hereinafter abbreviated as RW, are part of lurah work and are institutions formed through RW deliberative forums in their working areas which are determined by the Village Head., Treasurer and Section Head in the RW management set by the lurah.

This research is similar to the previous research, namely discussing (Risnanto, Study, Informatics, Engineering, \& Service, 2017) In a country that adheres to a political system of democracy, voting is used to make state decisions that are very crucial, among others, to elect people's representatives, or to elect a new leader of the country. However, not all citizens can vote in voting.

In support of realizing Pancasila democracy in the election of the Chairperson of the Rukun Warga (RW), in organizing the election of the Rukun Chairperson Citizens can apply with electronic voting or abbreviated as E-Voting.

\section{Literature REVIEW}

Voting according to (Darmawan, Nurhandjati, \& Kartini, 2014) can be interpreted as an act of using the right to vote in an election exercise. Whereas EVoting according to (Darmawan et al., 2014) can simply be interpreted as the use of suffrage in an election by using technology assistance electronically. General requirements in e-voting according to (Haryati, Adi, \& Suryono, 2014) in the quotation from Cetinkarya so that it does not come out of the voting framework as follows: 
Table 2. Voting Framework

\begin{tabular}{|l|l|}
\hline Privacy & $\begin{array}{l}\text { Nobody knows what } \\
\text { choices the voters choose }\end{array}$ \\
\hline Eligibility & $\begin{array}{l}\text { Only voters who meet the } \\
\text { requirements are eligible } \\
\text { to vote }\end{array}$ \\
\hline Uniqueness & $\begin{array}{l}\text { Each voter is only entitled } \\
\text { to choose one }\end{array}$ \\
\hline Receiptfreeness & $\begin{array}{l}\text { Voters do not tell anyone } \\
\text { what their choice is for } \\
\text { voting, this is to prevent } \\
\text { the sale and purchase of } \\
\text { votes }\end{array}$ \\
\hline Fairness & $\begin{array}{l}\text { There is no partial } \\
\text { calculation before the end } \\
\text { of the voting period to } \\
\text { ensure that all candidates } \\
\text { are given a fair decision. }\end{array}$ \\
\hline Transparency & $\begin{array}{l}\text { The whole voting process } \\
\text { must be transparent using a } \\
\text { screen that can be used to } \\
\text { publish the election } \\
\text { process. }\end{array}$ \\
\hline Accuracy & $\begin{array}{l}\text { The accuracy of the voting } \\
\text { results, the votes that have } \\
\text { been entered cannot be } \\
\text { changed. }\end{array}$ \\
\hline Robustness & $\begin{array}{l}\text { All parties cannot interfere } \\
\text { with or influence the final } \\
\text { selection and calculation. }\end{array}$ \\
\hline
\end{tabular}

Voting or voting which is an important part of elections is a method in which some or a group of people make a decision, both political, social and public decisions (Dwumfuo \& Paatey, 2011). Not only in general elections or elections is an important part of the democratic process to determine a decision that can be accepted by everyone (Cedo, Ahullo, Roca, \& Viejo, 2012). The E-Voting system allows for simpler oversimplification and significantly reduces total election costs (Dwumfuo \& Paatey, 2011). According to (BPPT, 2010) E-Voting is a system that utilizes electronic devices and processes digital information to make ballots, vote, count votes, broadcast votes and maintain and produce audit trails. To reduce the information constraints (Samudi, Brawijaya, \& Widodo, 2018), the election should have used an information system that will produce accurate and fast data on determining the results.

\section{Proposed Method}

The method used in electoral research is the Software Development Life Cycle software development cycle or commonly referred to as SDLC based (Pressman, 2012) starting from the following Communication, Planning, Modeling, Construction, and Deployment:

1. Communication

The analysis is needed to determine a need that will be applied to the system that will be made.

2. Planning

At this stage, a system structure design is needed that visually describes the system workflow that will be created.

3. Modeling

After analyzing and designing directly applied to the writing program.

4. Construction

This stage is the stage where after the program is typed in the programming language will be tested about the success of the program based on the analysis that has been made.

5. Deployment

At this stage, the last stage to implement the program has been made.

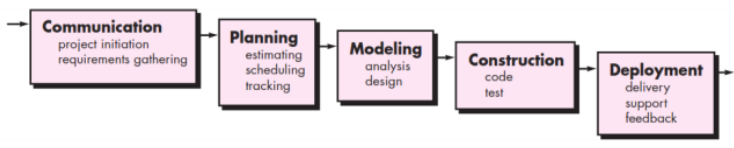

Fig 1. Model SDLC Waterfall

\section{CONCLUSION AND SUgGeSTION}

4.1. Needs Analysis

To avoid the problems faced, a needs analysis is needed so that the system produced can provide or fulfill the needs in solving problems encountered when designing the system. The following is an analysis of the requirements in overcoming a problem that will be faced.

1. The system can record the candidates who will be selected.

2. The system can record the voters who will choose the candidates for leadership.

3. The system will display information about the election schedule.

4. The system will display the results of the elections that have been carried out 


\subsection{System Design}

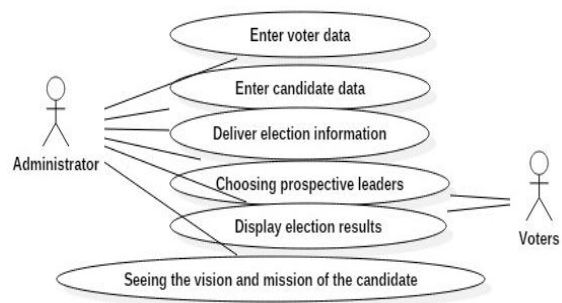

Fig 2. Use Case Selection Chart

1. Enter Voter Data, as an administrator can enter voter data consisting of voter identities, such as voter identity, voter name, address, and password.

2. Incorporating Candidate candidates, as administrators can enter candidates for future leaders whose function is to explain the vision and mission objectives or achievements that will be done as long as they are elected leaders.

3. Delivering election information, the administrator will inform the election scheduled to be carried out, along with the terms and flow of the election process until the election results.

4. Choosing Prospective Leaders, as administrators and voters can be as well as in the election of RW heads based on their choices.

5. Seeing the Vision and Mission Candidates, administrators and voters can see the mission and vision of the candidates of the candidates.

6. Showing the results of the election, as an administrator will display the results of the selection process that has been carried out with data stored in the system.

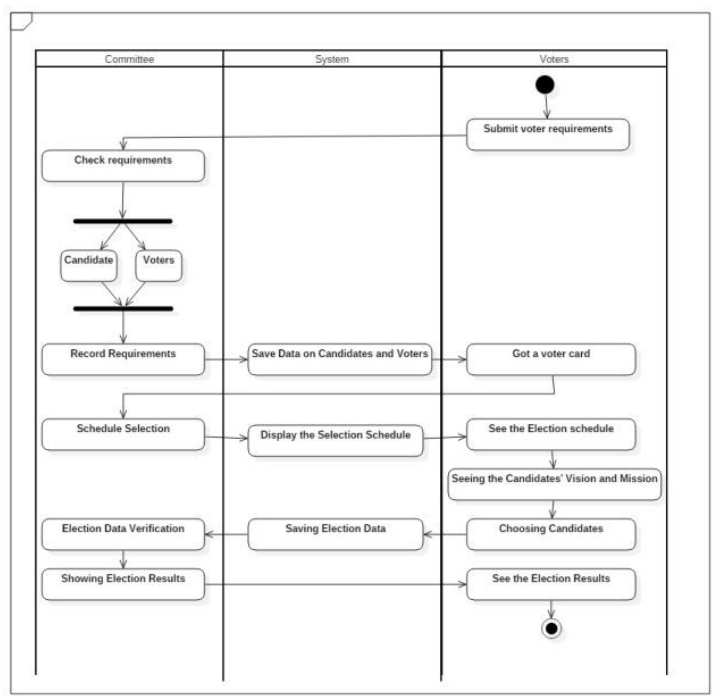

Fig 3. Selection Activity Diagram

\subsection{Testing the Testing program}

That will be conducted by researchers related to this research is by using WAPT, the following are the results of the tests that have been carried out.

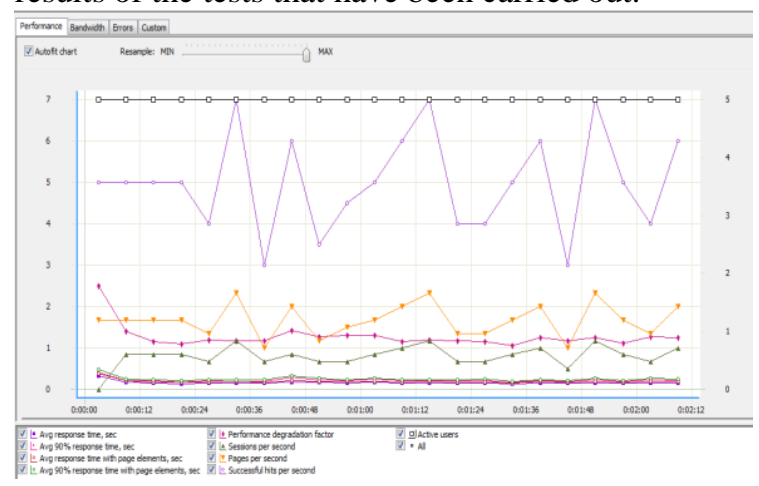

Fig 4. Testing of WAPT

\subsection{Application of the program}

The following is the interface display in the use of RW-based voting RW, in this interface enter the registered identity number, and the password that has been obtained.

1. Election Committee Login Page

On this Login Page, there are fields that must be filled in such as identification number and password.

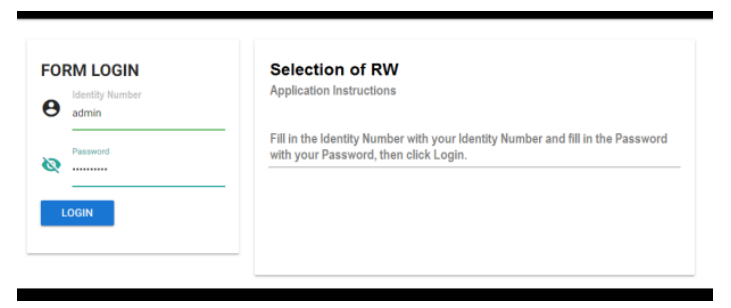

Fig 5. Login page

2. Main Page of the Election Committee On this page, there are several menus that are displayed such as the voter list menu which contains a voter list and added voter list. The Candidate List menu contains a list of candidates, in the vision and mission, adding candidates, and election results. The Announcement Info menu consists of an announcement list, and an announcement is added. As well as the menu above, the Voting Menu serves to start voting 




Fig 6. Page of the Election Committee

3. E-Voting Scheduling Menu

On this menu, the committee can set the EVoting scheduling selection by entering the start and start dates, and entering the hours when the E-Voting scheduling is finished and the end date.

\section{Q. admin -}

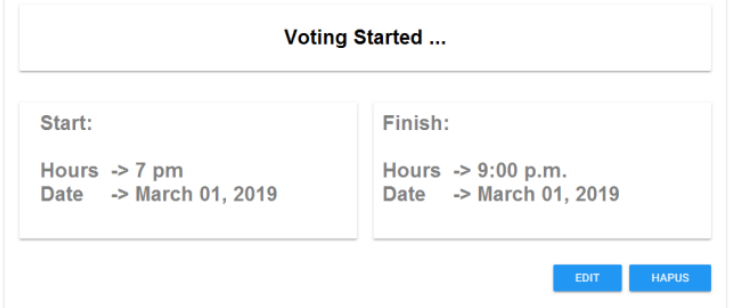

Fig 7. Page of the Election Committee

\section{Page Selector Menu}

In this menu, voters have the right to choose candidates who are deemed entitled to be chosen according to the conscience of the voters by selecting numbers and details will be displayed from the candidate's data and the vote button to vote.

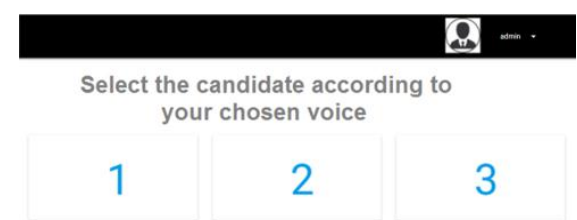

Fig 8. List of Candidate Numbers

\section{Pages for voting}

In this menu, voters can see candidate data such as photos, names, and the candidates' vision and the mission will be displayed. If you are sure of the choice, the vote button can now be clicked on.

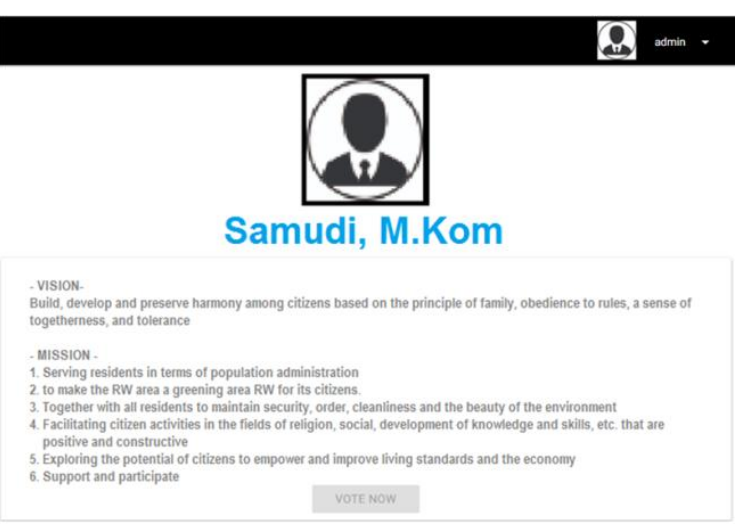

Fig 9. Giving E-Voting

6. Results of E-Voting elections

In the results of the election with voting, the highest score will win the election

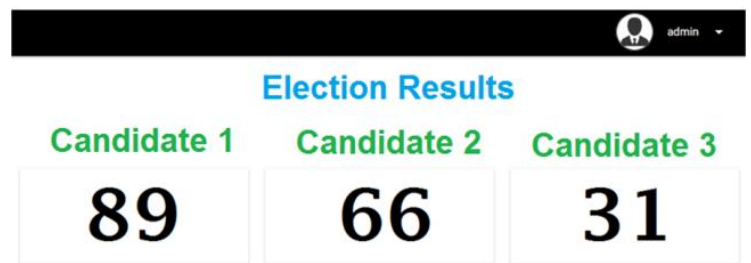

Fig 10. E-Voting Results

\section{Conclusion ANd Suggestion}

\subsection{CONCLUSION}

1. In E-Voting elections can reduce the problems of the registration process until the results displayed at the end of the selection process are directly on the voting.

2. The application of e-Voting will save the cost of implementing elections because there is no need to print ballot papers and other voter registration forms. In addition, the e-voting device can be used again in the following period.

3. On E-Voting, it has resembled the election's legal elections such as direct, free, confidential, honest and fair elections. Information displayed on the results of the election will display accurate data.

4. E-voting will facilitate the recapitulation of vote counts quickly.

5. E-voting can minimize fraud during the selection process.

6. The implementation of E-Voting can reduce operational costs when the election takes place. Testing with WAPT can minimize deficiencies when elections are conducted with E-Voting. 


\subsection{SUGGESTIONS}

E-Voting can be synchronized with E-KTP data in the Directorate General of Population and Civil Registration of the Ministry of Home Affairs. So that the collection of voter data and prospective leaders is more accurate. The mapping of polling stations is carried out so that it can be applied in various regions. Making aspects of security trust and aspects of data transparency to change the community paradigm regarding E-Voting election procedures. Can be developed up to the mobile network to make the selection process easier.

\section{REFERENCES}

BPPT. (2010). E-Voting in the Glasses of Policy and Supervision, p. 1. Retrieved from https://www.bppt.go.id/teknologiinformasi-energi-dan-material/439-evoting-dalam-klasses-keb Policy-danpengawasan

Cedo, R., Ahullo, J., Roca, J.., \& Viejo, A. (2012). Study on poll-site voting and verification systems. In Computers \& Security (pp. 9891010).

Darmawan, I., Nurhandjati, N., \& Kartini, E. (2014). Understanding E-voting: Reflecting on the Experience of Other Countries and Jembrana (Bali).

Dwumfuo, O., \& Paatey, E. (2011). The Design of an Electronic Voting System The Design of an Electronic Voting System. Research Journal of Information Technology, 3 (September), 2 .

Haryati, Adi, K., \& Suryono. (2014). The Electronic Voting System Uses the E-Voting Poll Site Model. Journal of the Business Onformation System, 1, 67-74.

Governor's office. (2016). Regulation of the Governor of the Special Capital Region of Jakarta. Retrieved from http://selatan.jakarta.go.id/hukum/downloa d_file/34PERGUB 1 YEAR 2016.pdf

Pressman, R. S. (2012). Software engineering. Yogyakarta: ANDI.
Risnanto, S., Studi, P., Informatika, T., Teknik, F., \& Service, S. M. (2017). Electronic voting application / e-voting uses technology short message service and at command, 10 (1). https://doi.org/10.15408/jti.v10i1.6811

Samudi, S., Brawijaya, H., \& Widodo, S. (2018). Application of the Waterfall Method in a Web-Based Waste Bank Information System. Journal of Computer Science and Technology, 3 (2), 145-150. Retrieved from http://ejournal.nusamandiri.ac.id/ejurnal/ind ex.php/jitk/article/view/668/417 